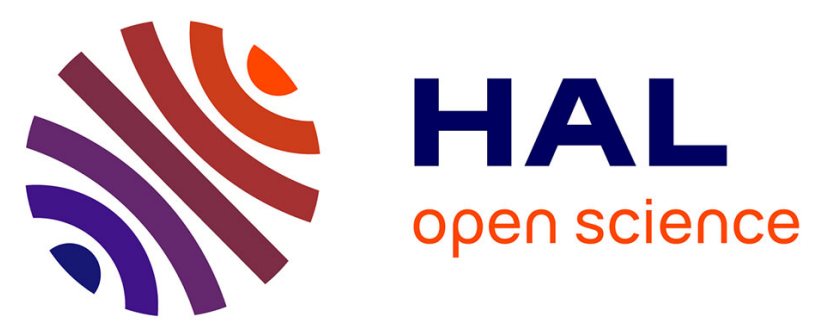

\title{
Ambient particulate matter (PM2.5): Physicochemical characterization and metabolic activation of the organic fraction in human lung epithelial cells (A549)
}

Sylvain Billet, Guillaume Garçon, Zeina Dagher, Anthony Verdin, Frédéric Ledoux, Fabrice Cazier, Dominique Courcot, Antoine Aboukais, Pirouz Shirali

\section{To cite this version:}

Sylvain Billet, Guillaume Garçon, Zeina Dagher, Anthony Verdin, Frédéric Ledoux, et al.. Ambient particulate matter (PM2.5): Physicochemical characterization and metabolic activation of the organic fraction in human lung epithelial cells (A549). Environmental Research, 2007, 105 (2), pp.212-223. 10.1016/j.envres.2007.03.001 . hal-03385239

\section{HAL Id: hal-03385239 \\ https://hal.science/hal-03385239}

Submitted on 20 Oct 2021

HAL is a multi-disciplinary open access archive for the deposit and dissemination of scientific research documents, whether they are published or not. The documents may come from teaching and research institutions in France or abroad, or from public or private research centers.
L'archive ouverte pluridisciplinaire HAL, est destinée au dépôt et à la diffusion de documents scientifiques de niveau recherche, publiés ou non, émanant des établissements d'enseignement et de recherche français ou étrangers, des laboratoires publics ou privés. 


\title{
AMBIENT PARTICULATE MATTER (PM 2.5$)$ : PHYSICOCHEMICAL CHARACTERIZATION AND METABOLIC ACTIVATION OF THE ORGANIC FRACTION IN HUMAN LUNG EPITHELIAL CELLS (A549)
}

\author{
Sylvain BILLET ${ }^{1}$, Guillaume GARÇON ${ }^{1}$, Zeina DAGHER ${ }^{1}$, Anthony VERDIN ${ }^{1}$, \\ Frédéric LEDOUX ${ }^{2}$, Fabrice CAZIER ${ }^{3}$, Dominique COURCOT ${ }^{2}$, Antoine \\ ABOUKAIS ${ }^{2}$, Pirouz SHIRALI ${ }^{1}$
}

1. LCE EA2598, Toxicologie Industrielle et Environnementale, Université du Littoral - Côte d'Opale, Maison de la Recherche en Environnement Industriel de Dunkerque 2, 189A, Avenue Maurice Schumann, 59140 Dunkerque, France;

2. LCE EA2598, Catalyse et Environnement, Université du Littoral - Côte d'Opale, Maison de la Recherche en Environnement Industriel de Dunkerque 1, 145, Avenue Maurice Schumann, 59140 Dunkerque, France;

3: Centre Commun de Mesures, Université du Littoral - Côte d'Opale, Maison de la Recherche en Environnement Industriel de Dunkerque 1, 145, Avenue Maurice Schumann, 59140 Dunkerque, France.

Corresponding Author: Pr Pirouz SHIRALI, LCE EA2598, Toxicologie Industrielle et Environnementale, MREI 2, ULCO, 189A, Avenue Maurice Schumann, 59140 Dunkerque, France; Phone number: +33-3-28237610; Fax number: +33-3-28237171; E-mail: Pirouz.Shirali@univ-littoral.fr 


\begin{abstract}
To contribute to complete the knowledge of the underlying mechanisms of action involved in air pollution particulate matter (PM)-induced cytotoxicity, an aerosol was collected in Dunkerque, a French seaside City heavily industrialized. In this work, we focused our attention on its physical and chemical characteristics, its cytotoxicity, and its role in the induction of the volatile organic compound (VOC) and/or polycyclic aromatic hydrocarbon (PAH)-metabolizing enzymes in human lung epithelial cells (A549). Size distribution showed that $92.15 \%$ of the collected $\mathrm{PM}$ were $\mathrm{PM}_{2.5}$ and the specific surface area was $1 \mathrm{~m}^{2} / \mathrm{g}$. Inorganic (i.e. $\mathrm{Fe}, \mathrm{Al}, \mathrm{Ca}, \mathrm{Na}, \mathrm{K}, \mathrm{Mg}, \mathrm{Pb}$, etc.) and organic (i.e. VOC, $\mathrm{PAH}$, etc.) chemicals were found in collected PM, revealing that much of them derived from wind-borne dust from the industrial complex and the heavy motor vehicle traffic. The thermal desorption study indicated that organic chemicals were not only adsorbed onto the surface but also highly incrusted in the structure of PM. The lethal concentrations at $10 \%$ and $50 \%$ of collected PM were $23.72 \mu \mathrm{g} / \mathrm{mL}$ (or $6.33 \mu \mathrm{g} / \mathrm{cm}^{2}$ ) and $118.60 \mu \mathrm{g} / \mathrm{mL}$ (or $31.63 \mu \mathrm{g} / \mathrm{cm}^{2}$ ), respectively. The VOC and/or PAH-coated onto PM induced significant increases in mRNA expressions of cytochrome P450 (cyp) 1a1, cyp2e1, cyp2f1, nadph quinone oxydo-reductase1 , and glutathione s-transferase-pi 1, versus controls. Hence, we concluded that the metabolic activation of the very low doses of VOC and/or PAH-coated onto the inorganic condensation nuclei from Dunkerque City's PM is one of the underlying mechanisms of action closely involved in its cytotoxicity in human lung epithelial cells.
\end{abstract}

KEY-WORDS: A549 cells; particulate matter; physical and chemical characteristics; cytotoxicity; metabolic activation; volatile organic compounds; polycyclic aromatic hydrocarbons 


\section{INTRODUCTION}

Air pollution particulate matter (PM) is a complex mixture of chemical and/or biological elements, such as metals, salts, carbonaceous material, volatile organic compounds (VOC), polycyclic aromatic hydrocarbons (PAH), endotoxins, which can in fact interact and, potentially, adsorb onto condensation nuclei (Alfaro-Moreno et al., 2002; Schlesinger et al., 2006; Soukup and Becker, 2001). However, the majority of toxicological studies published on PM toxicity have been conducted using complex mixtures, yet their physical and chemical characteristics are usually not well established and the influence of the elements-coated onto PM are often neglected (Hetland et al., 2004).

The adverse effects of ambient PM on human health have been a concern for decades (Brunekreef and Holgate, 2002). Attempts to provide linkages between adverse health effects and PM properties have significantly increased (Englert, 2004). However, despite intensive investigation, the underlying mechanisms of PM-related adverse health effects are still incompletely understood, but a hypothesis currently under investigation is that organic compound-coated onto PM could played a key role in their toxicity (Liden et al., 2003; Nel et al., 2001; Osornio-Vargas et al., 2003). Hence, a better knowledge of the physical and chemical characteristics of PM, which depend from the sources, the emission intensity, and the molecular interactions between inorganic and organic components, constitutes required information for the evaluation of PM toxicity (Buschini et al., 2001; Schlesinger et al., 2006). Nevertheless, the physical and chemical properties of air pollution PM revealed to be unsatisfactory to predict its biological reactivity (Baulig et al., 2004).

Various lung target cells take significantly part in the metabolic activation of inhaled organic chemicals (Dahl and Lewis, 1993; Hukkanen et al., 2000; Spivack et al., 2003; Willey et al., 1996). The superfamily of cytochrome P450 (CYP) is commonly known as being the main system, which catalyses the oxidation and the subsequent activation of such organic chemicals. In human lungs, VOC and PAH, which require metabolic activation to biologically reactive intermediates to elicit their cytotoxic effects, are mainly metabolized by CYP2E1/CYP2F1, and CYP1A1, respectively (Garçon et al., 2004a; 2004b; Rossi et al., 1999; Vakharia et al., 2001a; 2001b). Produced epoxy compounds are thereafter rearranged either directly, out of phenol for benzene, or indirectly, through their conversion into dihydrodiols, mainly catalyzed by the microsomal epoxyde hydrolase (mEH) (Bauer et al., 2003). Such metabolites will be able to undergo again an oxidation by the same CYP (Koop et al., 1989). In lungs, the myelotoxic quinone-derivatives compounds are detoxified by the NADPH quinone oxydo-reductase-1 (NQO1) in hydroxyquinones (Bauer, 2003; Jaiswal, 2000; Wiemels et al., 1999). Once metabolized by the phase I enzymes, ultimate reactive intermediates can rearrange themselves or exert direct adverse effects at molecular and/or cellular levels. The next metabolic step may involve the conjugation of such highly reactive metabolites in more hydrophilic metabolites, mainly catalyzed by the glutathione Stransferases (GST) (Hayes et al., 1995a; 1995b; Thier et al., 2003).

Hence, to improve the knowledge of the underlying mechanisms involved in PMinduced cytotoxicity, with a particular interest of the role of the organic chemicals, the PM sample was collected in Dunkerque, a French seaside City characterized by the proximity of a 
lot of industrial activities and a heavy motor vehicle traffic. Its physical and chemical characteristics were carried out. We were interested in the PM-induced cytotoxicity in adherent A549 cells, and in the metabolic activation of the coated organic chemicals by these target cells, through the determination of the gene expressions of cyplal, cyp2e1, cyp2f1, $m e h, n q o l, g s t-\mu 1, g s t-\mu 3$, and $g s t-\pi l$. To better define the accurate role of the organic fraction, titanium dioxide $\left(\mathrm{TiO}_{2}\right)$ and PM having undergone a thermal desorption (dPM) were also included in the experimental design of this multi-step study as negative controls.

\section{MATERIALS AND METHODS}

\section{Chemicals}

Minimum essential medium (MEM) with Earle's salts, fetal bovine serum (FBS), Lglutamin, penicillin/streptomycin solution, and sterile Phosphate-Buffered Solution (PBS) were from InVitrogen-Life Technologies (Cergy Pontoise, France). Titanium (IV) oxide powder (99\%) was from Acros Organics (Noisy Le Grand, France). Benzene and toluene were provided by Sigma-Aldrich (St-Quentin Fallavier, France). Cell Proliferation ELISA (BrdU), Cell Proliferation Reagent (WST-1), and Cytotoxicity Detection Kit (LDH), on the one hand, and all the reagents (except primers) for reverse transcription (RT) and polymerase chain reaction (PCR), on the other hand, were from Roche Diagnostics (Meylan, France). Proligo France SAS (Paris, France) synthesized primer pairs for PCR.

\section{Methods}

Figure 1 showed the experimental design of this multi-step approach.

\section{PM Sampling, Physical and Chemical Characteristics, and Outgassing}

PM Sampling: PM was collected in Dunkerque (51 $\left.{ }^{\circ} 04^{\prime} \mathrm{N} ; 2^{\circ} 38^{\prime} \mathrm{E}\right)$, a French sea-side City located on the southern coast of the North-Sea, using high volume Sierra model 235 cascade impactor (Sierra Anderson, Smyna, GA, USA). The sampling method has already been published elsewhere (Dagher et al., 2005). Briefly, plates were mounted without any filters and no back up filter was used to maintain a constant aspiration flow rate $\left(68 \mathrm{~m}^{3} / \mathrm{h}\right)$ for a period of 2 weeks. The lowest stage was doubled to increase the efficiency of smallest particle (PM0.33) sampling. Collection was done continuously during 9 months, from January to September, to include seasonal changes, and impacting system was changed every 15 days; two identical systems were used alternatively. Meteorological data (i.e. wind speed, wind direction, temperature) were obtained from Météo France. The collection urban zone is characterized by the proximity of industrial activities (i.e. iron and steel industry, aluminum industry, oil refinery, basic chemistry, pharmaceutical industry, plant health production, food industry, etc.), and a heavy motor vehicle traffic. After sampling, impacting plates were dried under laminar flow bench during $48 \mathrm{~h}$, and then PM was removed and stocked at $4^{\circ} \mathrm{C}$. About $2 \mathrm{~g}$ of PM have been collected by this way and carefully homogenized.

PM physical characterization: Scanning electron microscopy coupled with energy dispersive X-ray analysis (SEM-EDX; LeoTM 438 VP microscope and IXRF analysis 
system; Zeiss SAS, Le Pecq, France) was used to perform single particle analysis and also to determine the PM size distribution. Prior to the analysis, PM was suspended in a n-hexane solution using ultrasonic treatment, and then filtered through a nucleopore filter to obtain well-distributed and dispersed PM, without agglomerates, as suitable for the SEM-EDX analysis. After the filter carbon-coating, the determination of PM size has been done in the automatic mode with SEM operating conditions as follows: accelerating voltage: $25 \mathrm{keV}$; intensity: $300 \mathrm{nA}$, and magnification: $x$ 5000. The minimal observable size was $0.1 \mu \mathrm{m}$. The total number of studied particles in SEM-EDX was about 2500. Specific surface area has been measured according to the Brunauer, Emmett, and Teller method using a porosimeter Sorptomatic 1990 Series (Thermo Electron Corporation, Courtaboeuf, France).

PM chemical characterization: The analytical procedure for inorganic element determination consisted of the acidic total digestion of PM, and the subsequent analysis by inductively coupled plasma-atomic emission spectrometry (ICP-AES) using a Varian Liberty II (Varian S.A., Coutaboeuf, France). The ion composition was determined with ionic chromatography $\left(\mathrm{Cl}^{-}, \mathrm{NO}_{3}{ }^{-}\right.$and $\left.\mathrm{SO}_{4}{ }^{2-}\right)$, and visible spectrophotometry $\left(\mathrm{NH}_{4}{ }^{+}\right)$. The analytical procedure for organic chemical determination consisted of a thermal desorption at $500^{\circ} \mathrm{C}$ coupled with cold trapping, prior gas chromatography-mass spectrometry (GC/MS) analyses on the Varian Saturn 4D apparatus (Varian France) equipped with a 60m J\&W DB1 MS column. Thermogravimetric and differential thermal analysis (TG-DTA) and specific surface area determinations were carried out to evaluate the efficiency of the desorption method.

PM Outgassing: In order to better determine the role of the organic fraction-coated onto PM in the induced-adverse effects in A549 cells, PM having undergone a thermal desorption at $400^{\circ} \mathrm{C}$ under secondary vacuum were used as negative controls (i.e. desorbed particulate matter, $\mathrm{dPM}$ ). Briefly, a progressive rise in temperature by $0,5^{\circ} \mathrm{C} / \mathrm{min}$ was applied to $\mathrm{PM}$ up to $400^{\circ} \mathrm{C}$, during $6 \mathrm{~h}$, under a pressure of $10^{-7} \mathrm{~Pa}$.

\section{Cells and Culture Conditions}

Adherent A549 cells derived from a type II-like human alveolar epithelial carcinoma (ATCC number: CCL-185) were cultured in sterile plastic flasks (Corning; Fisher Scientific Labosi SAS, Elancourt, France), in MEM with Earle's salts, containing: 5\% FBS, 1\% Lglutamin $(200 \mathrm{mM}), 1 \%$ penicillin $(10000 \mathrm{IU} / \mathrm{mL})$ and $1 \%$ streptomycin $(10000 \mu \mathrm{G} / \mathrm{mL})$ (In Vitrogen-Life Technologies), as described by Garçon et al. (2001). Exponentially growing cells were maintained at $37^{\circ} \mathrm{C}$, in a humidified atmosphere containing $5 \% \mathrm{CO}_{2}$. To avoid phenotypic changes affecting responsiveness to chemicals, all the A549 cells we used in the study of the cytotoxicity, on the one hand, and in the study of mRNA expression of VOC and/or PAH-metabolizing enzymes, on the other hand, derived from the same initial cell culture, not having undergone more than five passages.

\section{Study of PM Cytotoxicity}

PM cytotoxicity in A549 cells has been studied using four complementary methods: the incorporation of 5-bromo-2-deoxyuridine (BrdU) in cells (Cell Proliferation ELISA BrdU, Roche Diagnostics), the activity of the mitochondrial dehydrogenase (MDH) in cells (Cell Proliferation Reagent WST-1, Roche Diagnostics), the activity of lactate dehydrogenase $(\mathrm{LDH})$ in cell-free culture supernatants (Cytotoxicity Detection Kit LDH, Roche 
Diagnostics), and the colony forming method, as already described by Garçon et al. (2006). Briefly, to carry out the first three methods, A549 cells were seeded in 96-well culture microplates (Costar; Fisher Scientific Labosi SAS) at a density of $2 \times 10^{4}$ cells $/ 200 \mu \mathrm{L}$ culture media containing 18.84, 37.68, 56.52, 75.36 or $150.72 \mu \mathrm{g} \mathrm{PM} / \mathrm{mL}$ (or 11.42, 22.64, $34.25,45.67$ or $91.35 \mu \mathrm{g} \mathrm{PM} / \mathrm{cm}^{2}$ ) and incubated at $37^{\circ} \mathrm{C}$ in a humidified atmosphere containing $5 \% \mathrm{CO}_{2}$. Non-exposed cells were used as negative controls and Triton X-100 (2\%, $\mathrm{v} / \mathrm{v}$ )-exposed cells as positive controls. Accordingly, 16 replicates were chosen at random as control cells, 8 replicates per PM concentration as exposed cells, and 8 replicates as positive controls. After 24, 48 or $72 \mathrm{~h}$ of incubation, the incorporation of BrdU and the activities of MDH and LDH were evaluated, following to the manufacturer's instructions. Survival rates of PM-exposed A549 cells were determined using the colony forming method (Shirali et al., 1995). Briefly, proliferating cells were seeded in culture dishes (60 x $15 \mathrm{~mm}$; Corning; Fisher Scientific Labosi SAS): 10 culture dishes were chosen at random as control cells, and 5 culture dishes per PM concentration (i.e. $18.84,37.68,56.52,75.36$ or $150.72 \mu \mathrm{g} \mathrm{PM} / \mathrm{mL}$; or $4.61,9.22,13.83,18.45$ or $36.89 \mu \mathrm{g} \mathrm{PM} / \mathrm{cm}^{2}$ ) were designated at random as exposed cells. The values of the lethal concentrations at $10 \%$ and $50 \%$ ( $\mathrm{LC}_{10}$ and $\mathrm{LC}_{50}$, respectively) were calculated comparing the number of crystal violet-stained cell colonies in exposed culture dishes with the number in non-exposed culture dishes.

\section{Study of the mRNA Expression of VOC and/or PAH-Metabolizing Enzymes}

Cell Exposure: Depending on the incubation time, A549 cells were seeded at different density (i.e. $6 \times 10^{6}, 3 \times 10^{6}$ or $1.5 \times 10^{6}$ cells $/ 20 \mathrm{~mL}$ of culture media, respectively) in culture plastic flasks (Corning; Fisher Scientific Labosi SAS) and incubated at $37^{\circ} \mathrm{C}$, in a humidified atmosphere containing $5 \% \mathrm{CO}_{2}$. After $3 \mathrm{~h}$, culture supernatants were removed to eliminate non-adherent cells. Only living A549 cells were also incubated in the continuous presence of $\mathrm{PM}$ at their calculated $\mathrm{LC}_{10}$ (i.e. $23.72 \mu \mathrm{g} \mathrm{PM} / \mathrm{mL}$; or $6.33 \mu \mathrm{g} \mathrm{PM} / \mathrm{cm}^{2}$ ) or $\mathrm{LC}_{50}$ (i.e. 118.60 $\mu \mathrm{g} \mathrm{PM} / \mathrm{mL}$; or $31.63 \mu \mathrm{g} \mathrm{PM} / \mathrm{cm}^{2}$ ) for 24,48 or $72 \mathrm{~h}$ of incubation, without renewing the culture media. Non-exposed cells, $\mathrm{TiO}_{2}$ (geometric diameter $<0.2 \mu \mathrm{m}$ )-exposed cells, and dPM-exposed cells were used as negative controls. A549 cells were exposed to $\mathrm{TiO}_{2}$ at equivalent concentrations to inorganic $\mathrm{LC}_{10}$ (i.e. $\mathrm{Eq} \mathrm{LC}_{10}=19.42 \mu \mathrm{g} / \mathrm{mL}$; or $5.18 \mu \mathrm{g} / \mathrm{cm}^{2}$ ) or $\mathrm{LC}_{50}$ (i.e. $\mathrm{Eq} \mathrm{LC}_{50}=97.13 \mu \mathrm{g} / \mathrm{mL}$; or $25.90 \mu \mathrm{g} / \mathrm{cm}^{2}$ ), integrating thereby mass losses arising from the thermal desorption of the organic fraction. Benzene $(7 \mu \mathrm{M})$, toluene $(7 \mu \mathrm{M})$, and benzo(a)pyrene $(\mathrm{B}(\mathrm{a}) \mathrm{P} ; 1 \mu \mathrm{M})$-exposed cells served as positive controls for the induction of VOC and/or PAH-metabolizing enzymes (Garçon et al., 2001; 2004a; 2004b; Powley et al., 1999). For each incubation time (i.e. 24,48 or $72 \mathrm{~h}$ ), 8 culture flasks were chosen at random as control cells (i.e. incubated only with cultured media), 4 culture flasks per $\mathrm{TiO}_{2}$ or $\mathrm{dPM}$ concentration as negative control cells, 4 culture flasks per PM concentration as exposed cells, and 4 culture flasks per VOC or PAH concentration as positive controls.

Observation of the Organic Fraction-Coated onto PM-Exposed Cells: After $24 \mathrm{~h}$ of incubation, PM-exposed cells were observed using a CKX41 microscope equipped with a DP12 digital camera and a U-RFLT50 UV source (Olympus France S.A.S, Rungis, France) with Rhodamin ( $\lambda_{\text {excitation: }} 570 \mathrm{~nm}$; $\lambda_{\text {emission }} 590 \mathrm{~nm}$ ). 
Cell Sampling: After 24, 48 or $72 \mathrm{~h}$ of incubation, adherent cells were removed and centrifuged $\left(500 \mathrm{~g} ; 10 \mathrm{~min} ; 4^{\circ} \mathrm{C}\right)$. Cell pellets were washed twice with 5 -ml aliquots of cold phosphate-buffered saline $(0.01 \mathrm{M} ; \mathrm{pH}=7.2)$, and frozen at $-80^{\circ} \mathrm{C}$ until RNA extraction.

mRNA expression of VOC and/or PAH-metabolizing enzymes: Total RNA were extracted from A549 cell-aliquots using RNeasy Mini Kits (Qiagen). Conditions for the RT were published elsewhere (Garçon et al., 2004a). Highly specific primer pairs sequences are reported in the Table 1. PCR thermocycling conditions were as reported by Iwanari et al. (2002; i.e. cypla1), Macé et al. (1998; i.e. cyp2e1), Nichols et al. (2003; i.e. cyp2f1), Spivack et al. (2003; i.e. nqol, gst- $\mu 1$, gst- $\mu 3$, and $g s t-\pi l$ ), and Dubois et al. (2000; i.e. $\beta$-actin). After gel electrophoresis and ethidium bromide intercalation, PCR-amplified products were visualized under UV light and analyzed by a computerized video/densitometry system (Software: GelAnalyst ${ }^{\mathrm{TM}}$ v3.1FR; Vasse Industries, Lille, France).

\section{Statistical Analysis}

Treatment attribution at random has been made following an 11 element-permutation table. Results are expressed as mean values and standard deviations. For each incubation time (i.e. 24, 48 or 72 h), data from cell cultures exposed to negative controls, PM, and positive controls were compared with those from non-exposed cell cultures. Statistical analyses were performed by the Mann-Whitney U test (Software: SPSS for Windows, v10.05, 2000; Paris, France). Statistically significant differences were reported with p values $<0.05$.

\section{RESULTS AND DISCUSSION}

\section{PM Physical and Chemical Characteristics}

Aerosol sampling was realized using a high volume cascade impactor designed to collect PM with a size $\leq 5 \mu \mathrm{m}$. PM size distribution (Figure 2) revealed that it was in the size range $0.33-5.0 \mu \mathrm{m}$ with a peak at $0.45 \mu \mathrm{m}$. Sampling restrictions were also respected insofar as $98.5 \%$ of PM have a size $<5 \mu \mathrm{m}$. The highest number of collected PM was also detected in size classes including PM with a size $\leq 2.5 \mu \mathrm{m}$ : 0-0.5 $\mu \mathrm{m}$ (33.63\%), 0.5-1.0 $\mu \mathrm{m}(30.61 \%)$, 1.0-1.5 $\mu \mathrm{m}$ (14.33\%), 1.5-2.0 $\mu \mathrm{m}$ (8.69\%), and 2.0-2.5 $\mu \mathrm{m}$ (4.89\%). Cumulative frequencies of $\mathrm{PM}_{1}$ and $\mathrm{PM}_{2.5}$ (i.e. $64.24 \%$ and $92.15 \%$, respectively) indicated that they were able to penetrate to the alveolar region of the lung to exert their toxicity (Harrison and Yin, 2000). According to epidemiological evidence, the greatest health risks correlate with smaller PM (Levy et al., 2000). Electronic microscopy observations showed structure differences in Fe oxide particles according to their origins: the anthropogenic ones were also characterized by a spherical form due to high temperature manufacturing process like blast furnace (Figure 3). Reported low sizes conferred to collected PM a relatively high specific surface area (i.e. 1 $\mathrm{m}^{2} / \mathrm{g}$ for $\mathrm{PM}$, and $50 \mathrm{~m}^{2} / \mathrm{g}$ for $\mathrm{dPM}$ ), which could exacerbate their reactivity and allow the adsorption of other chemicals (Warren, 2002).

A total of 20 inorganic elements were found in Dunkerque City's PM (Figure 4). Among them, $\mathrm{Fe}, \mathrm{Al}, \mathrm{Ca}, \mathrm{Na}, \mathrm{Pb}, \mathrm{Mg}$, and $\mathrm{Mn}$ were the most abundantly present and 
constitute not only elements usually associated with natural environment (i.e. $\mathrm{Ca}, \mathrm{Mg}, \mathrm{Na}$ ), but also so-called anthropogenic inorganic elements (e.g. $\mathrm{Al}, \mathrm{Mn}, \mathrm{Pb}, \mathrm{Zn}$ ). Ionic species were detected: $\mathrm{SO}_{4}{ }^{2-}, \mathrm{NO}_{3}{ }^{-}, \mathrm{Cl}^{-}, \mathrm{NH}_{4}{ }^{+}$. An exhaustive determination of the organic chemical-coated onto $\mathrm{PM}$ was realized using a thermal desorption at $500^{\circ} \mathrm{C}$ coupled with cold trapping, prior GC/MS analyses (Table 2). TG-DTA curves performed under air evidenced the presence of several thermal phenomena (Figure 5). At first, at low temperature $\left(146^{\circ} \mathrm{C}\right)$, an endothermic peak was ascribable to the gypsum dehydration in the collected PM (Figure 5a). In the temperature range $200-650^{\circ} \mathrm{C}$, exothermic reactions were pointed at $315^{\circ} \mathrm{C}, 412^{\circ} \mathrm{C}$ et $498^{\circ} \mathrm{C}$. These observations can be considered as a good evidence of the presence of organic compounds in the PM. As the experiment has been performed under oxidative conditions, the combustion of organic and carbonaceous compounds lead to exothermic phenomena recorded at $315^{\circ} \mathrm{C}$ and $412^{\circ} \mathrm{C}$. The exothermic peak detected at $498^{\circ} \mathrm{C}$ could be related to the oxidation of amorphous carbon black. The comparison between the TG-DTA curves from collected PM (Figure 5a) and $500^{\circ} \mathrm{C}-\mathrm{GC} / \mathrm{MS}$-analyzed PM (Figure 5b) revealed a decrease in the intensity of the first exothermic peak, showing partial desorption of the organic chemicals. Indeed, the $\mathrm{PM}$ thermal desorption at $500^{\circ} \mathrm{C}$ allowed a relative increase of the specific surface area (i.e. $28 \mathrm{~m}^{2} / \mathrm{g}$ vs PM: $1 \mathrm{~m}^{2} / \mathrm{g}$ ), suggesting that some organic chemicals remained coated. Various VOC (i.e. benzene, toluene, xylene, etc.), PAH (i.e. anthracene, fluoranthene, pyrene, etc.), and paraffins, were mainly detected. Accordingly, transition metals, VOC and PAH are often associated with PM, either through adherence to the core particle or as an integral component of the particle (Dreher et al., 1997; Monn and Becker, 1999; Nel et al., 2001). Moreover, PAH concentrations in Dunkerque City's PM were close to those in other PM collected in two locations in Paris (Baulig et al., 2004). The chemical composition of Dunkerque City's PM was also closely related to the anthropogenic emission sources located near the sampling site; apart the heavy motor vehicle traffic, iron and steel industry, aluminum industry, oil refinery, basic chemistry, pharmaceutical industry, and food industry must be cited. The collected PM consisted in a very complex mixture of chemicals, generally present at relatively low doses, thereby rendering very difficult the share of toxicity ascribable to the different fractions (inorganic vs organic, notably).

\section{PM Outgassing}

To better define the role of the organic fraction, PM having undergone a thermal desorption at $400^{\circ} \mathrm{C}$ under secondary vacuum (i.e. dPM) was included as negative controls. The differences from the TG-DTA curves between dPM and PM showed that this outgassing method conserved inorganic structures but strongly desorbed organic chemicals (Figure 5c). The TG-DTA data showed the difference of weight losses suffered by PM and dPM between 100 to $550^{\circ} \mathrm{C}: 24.5$ and $8.7 \%$, respectively (Figures $5 \mathrm{a}$ and $5 \mathrm{c}$ ). The remove of the organic fraction-coated onto PM using this outgassing method induced highly increase of the specific surface area; dPM: $50 \mathrm{~m}^{2} / \mathrm{g}$ vs PM: $1 \mathrm{~m}^{2} / \mathrm{g}$. Hence, the organic fraction was also not just coated-onto PM but firmly incrusted in the inorganic condensation nuclei present in the PM.

\section{Observation of the Organic Fraction-Coated onto PM-Exposed Cells.}

In the Figure 6a, PM seemed to be internalized by A549 cells. Using fluorescence illumination, the organic fraction-coated onto internalized particles could be observed (Figure 
6b). Moreover, in dPM-exposed A549 cells, few remaining organic chemical-coated onto dPM were seen, suggesting the incomplete desorption of the organic fraction despite the employed outgassing method (data not shown).

\section{PM Cytotoxicity}

Thereafter, we focused our attention on the cytotoxicity of Dunkerque City's PM in A549 cells. Table 3 shows that the incorporation of BrdU significantly decreased in PMexposed cells at concentrations $\geq 37.68 \mu \mathrm{g} \mathrm{PM} / \mathrm{mL}$ (or $22.84 \mu \mathrm{g} \mathrm{PM} / \mathrm{cm}^{2}$ ) in a concentrationdependent manner $(\mathrm{p}<0.05)$. Similarly, MDH activity decreased in A549 cells 24 or $48 \mathrm{~h}$ after their exposure to $\mathrm{PM}$ at concentrations $\geq 37.68 \mu \mathrm{g} \mathrm{PM} / \mathrm{mL}$ (or $22.84 \mu \mathrm{g} \mathrm{PM} / \mathrm{cm}^{2} ; \mathrm{p}<0.05$ ), or $72 \mathrm{~h}$ after their exposure to $\mathrm{PM}$ at concentrations $\geq 75.36 \mu \mathrm{g} \mathrm{PM} / \mathrm{mL}$ (or $45.67 \mu \mathrm{g} \mathrm{PM} / \mathrm{cm}^{2}$; $\mathrm{p}<0.05)$. Concentration-dependent decreases in the incorporation of BrdU and activity of $\mathrm{MDH}$ in PM-exposed cells suggest the alteration of cellular division and mitochondrial metabolism, respectively. Significant increases of extracellular LDH activity were observed in A549 cells $72 \mathrm{~h}$ after their exposure to $150.72 \mu \mathrm{g} \mathrm{PM} / \mathrm{mL}$ (or $91.35 \mu \mathrm{g} \mathrm{PM} / \mathrm{cm}^{2} ; \mathrm{p}<0.001$ ), and indicated a late disturbance of membrane integrity and/or permeability. Results of the colony-forming method showed a concentration-dependent effect in proliferating A549 cells. That method allowed the calculation of $\mathrm{LC}_{10}\left(23.72 \mu \mathrm{g} \mathrm{PM} / \mathrm{ml}\right.$; or $\left.5.81 \mu \mathrm{g} \mathrm{PM} / \mathrm{cm}^{2}\right)$ and $\mathrm{LC}_{50}$ (118.60 $\mu \mathrm{g} \mathrm{PM} / \mathrm{ml}$; or $29.03 \mu \mathrm{g} \mathrm{PM} / \mathrm{cm}^{2}$ ) (Figure 7). Dagher et al. (2005), studying the cytotoxicity of these PM in embryonic cells derived from human lung epithelium (L132 cell line $)$, reported $\mathrm{LC}_{10}\left(18.84 \mu \mathrm{g} / \mathrm{ml}\right.$; or $\left.4.61 \mu \mathrm{g} \mathrm{PM} / \mathrm{cm}^{2}\right)$ and $\mathrm{LC}_{50}(75.36 \mu \mathrm{g} / \mathrm{ml}$; or $18.45 \mu \mathrm{g}$ $\mathrm{PM} / \mathrm{cm}^{2}$ ) quite different, mainly arising from their different origin (normal vs carcinoma).

\section{mRNA Expression of VOC and/or PAH-Metabolizing Enzymes}

One of the main findings of this work was, therefore, the ability of the PM to induce the gene expression of cyplal, cyp2el, cyp2fl, and nqol. Indeed, a statistically significant induction of cyplal transcript was observed in A549 cells, 24, 48 and $72 \mathrm{~h}$ after their exposure to dPM at its $\operatorname{EqLC}_{10}(\mathrm{p}<0.05)$ and $\mathrm{EqLC}_{50}(\mathrm{p}<0.01)$, to $\mathrm{PM}$ at its $\mathrm{LC}_{10}(\mathrm{p}<0.01)$ and $\mathrm{LC}_{50}(\mathrm{p}<0.01)$, and to $\mathrm{B}(\mathrm{a}) \mathrm{P}(\mathrm{p}<0.01)$, compared to controls (Table 4). With regards to cyp2e1 gene expression, a significant increase was observed in A549 cells $24 \mathrm{~h}$ after their exposure to $\mathrm{PM}$ at its $\mathrm{LC}_{10}(\mathrm{p}<0.05)$ and $\mathrm{LC}_{50}(\mathrm{p}<0.05), 48 \mathrm{~h}$ after their exposure to $\mathrm{PM}$ at its $\mathrm{LC}_{10}(\mathrm{p}<0.05)$ and $\mathrm{LC}_{50}(\mathrm{p}<0.01)$, and $72 \mathrm{~h}$ after their exposure to $\mathrm{PM}$ at its $\mathrm{LC}_{50}(\mathrm{p}<0.01)$, versus controls (Table 4). Cell exposure to benzene or toluene caused an induction of cyp $2 e 1$ gene expression only after $24 \mathrm{~h}$ of exposure, versus controls $(\mathrm{p}<0.05)$. An increase of cyp $2 f 1$ transcript was observed in A549 cells, $24 \mathrm{~h}$ after their exposure to PM at its $\mathrm{LC}_{50}(\mathrm{p}<0.05)$, $48 \mathrm{~h}$ after their exposure to $\mathrm{PM}$ at its $\mathrm{LC}_{10}(\mathrm{p}<0.05)$ and $\mathrm{LC}_{50}(\mathrm{p}<0.01)$, and $72 \mathrm{~h}$ after their exposure to $\mathrm{PM}$ at its $\mathrm{LC}_{50}(\mathrm{p}<0.01)$, compared to controls (Table 4). Cell exposure to benzene induced enhanced mRNA expression of cyp2fl gene after $24 \mathrm{~h}$ of incubation, versus controls $(\mathrm{p}<0.05)$. No significant variations of meh transcripts were reported (data not shown). A significant increase in nqol mRNA expression were observed in A549 cells, 24, 48 and $72 \mathrm{~h}$ after their exposure to $\mathrm{PM}$ at their $\mathrm{LC}_{10}$ and $\mathrm{LC}_{50}(\mathrm{p}<0.05$ or $\mathrm{p}<0.01)$, and 24 and $48 \mathrm{~h}$ after their exposure to benzene $(\mathrm{p}<0.05)$, and $\mathrm{B}(\mathrm{a}) \mathrm{P}(\mathrm{p}<0.05$ and $\mathrm{p}<0.01$, respectively), versus non-exposed cells (Table 4). In agreement with these data, the transcription of cyplal gene seen in cells exposed to dPM confirmed that the employed outgassing method was not 
enough efficient to remove total PAH. In other respects, it is important to highlight that the gene induction of VOC functionalization enzymes (i.e. CYP2E1 and CYP2F1) by PM at their $\mathrm{LC}_{50}$ continued until $72 \mathrm{~h}$. In contrast, the induction of the gene transcripts of cyp2el and cyp $2 f 1$ by $\mathrm{PM}$ at their $\mathrm{LC}_{10}$ was limited to $48 \mathrm{~h}$. This result suggested the role of the physical vector of PM, which can enhance both the penetration and the retention of VOC into the cells, thereby enabling them to exert a more durable induction (Garçon et al., 2004a; 2004b; Vakharia et al., 2001a; 2001b). This hypothesis was supported by the observations of PMexposed cells by fluorescence microscopy, which showed the organic compounds-coated onto PM, even after their internalization. Within the aerosol, VOC-coated onto PM would be less sensitive to an early volatilization, as suggested by the fast but short induction of cyp $2 e 1$, cyp2fl and nqol genes in benzene and/or toluene-exposed A549 cells. With agreement with Hukkanen et al. (1997; 2002), Runge et al. (2001), and Sheets et al. (2004), we observed a great difference between the levels of cyp2el and cyp2fl transcripts in exposed A549 cells, suggesting the key role played by CYP2E1 in the metabolic activation of VOC. According to Jaiswal (2000) and Joseph et al. (1994), the gene expression of nqo1 increased in A549 cells exposed to the VOC-coated onto PM. However, cell exposure to toluene did not induce any gene expression of nqol. This can be explained by the limited role of this enzyme in the metabolic activation of toluene, which is mainly converted into benzyl alcohol after the oxidation of its methyl function; this latest is further oxidized in benzaldehyde and benzoic acid. The CYP2E1 and CYP1A1 respectively catalyze the oxidation of benzene and B(a)P in epoxides, which can be converted into diols, then in catechols and finally in quinone derivatives. The significant induction of nqol gene expression by PM, benzene or B(a)P is also in agreement with the literature. In contrast, meh gene has already been described as not inducible by organic chemicals (Bauer et al., 2003; Guengerich et al., 1996).

The epoxides producing through the first phase of the metabolic activation of organic chemicals are thereafter conjugated by GST- $\mu 1$, GST- $\mu 3$, GST- $\pi 1$ and GST- $\tau 1$, while phenols, hydroquinones, catechols and trihydroxybenzenes are conjugated with sulphates or glucuronides, before their excretion (Henderson et al., 1989; Rossi et al., 1999). The gene expression of $g s t-\mu 1$ could not be detected in A549 cells. Accordingly, $g s t-\mu 1$ is deleted in about half of Caucasians, and its gene expression cannot be observed in A549 cells (Bell et al., 1993). Similarly, whatever the considered exposure and incubation time, there was no significant variation of $g s t-\mu 3$ gene expression (data not shown). However, Macé et al. (1998) reported that this isoenzyme plays a major role in the detoxification. Statistically significant induction of $g s t-\pi l$ gene transcription was reported in A549 cells 48 or $72 \mathrm{~h}$ after their exposure to $\mathrm{PM}$ at its $\mathrm{LC}_{10}\left(\mathrm{p}<0.01\right.$ and $\mathrm{p}<0.05$, respectively) and $\mathrm{LC}_{50}(\mathrm{p}<0.01)$, benzene ( $\mathrm{p}<0.01$ and $\mathrm{p}<0.05$, respectively), toluene ( $\mathrm{p}<0.01$ and $\mathrm{p}<0.05$, respectively), and $\mathrm{B}(\mathrm{a}) \mathrm{P}(\mathrm{p}<0.05)$ (Table 5). In human lung, GST- $\pi 1$ is also the most active followed by GST$\mu 1$ and GST- $\mu 3$, whereas GST- $\tau 1$ lacks of activity (Piipari et al., 2003).

In conclusion, the physical and chemical characteristics of Dunkerque City's PM indicated that much of this PM derived from wind-borne dust from the industrial complex, and the heavy motor vehicle traffic. Taken together, these results supported that the metabolic activation of very low doses of VOC and/or PAH-coated onto the inorganic condensation 
nuclei of the Dunkerque City's PM is one of the underlying mechanisms of action closely involved in its cytotoxicity in human lung epithelial A549 cells.

\section{ACKNOWLEDGEMENTS}

The research described in this article has been supported by grants from the University of Littoral-Opale Coast, the Franco-British Interreg IIIA European Program (French Convention $\mathrm{n}^{\circ} 24$ ), the Research Institute of Industrial Environment, the Urban Community of Dunkerque, the French Ministry for Higher Education and Research (Convention $\mathrm{n}^{\circ}$ 16848-2005), and the Regional Council of Nord/Pas-de-Calais (Convention $n^{\circ} 0406$ 0092).

\section{REFERENCES}

Alfaro-Moreno, E., Martinez, L., García-Cuellar, C., Bonner, J.C., Murray, J.C., Rosas, I., Ponce-de-Leon Rosales, S., Miranda, J. and Osornio-Vargas, A.R., 2002. Biological effects induced in vitro by PM10 from three different zones of Mexico city. Environ. Health Perspect. 110; 715-720.

Bauer, A.K., Faiola, B., Abernethy, D.J., Marchan, R., Pluta, L.J., Wong, V.A., Roberts, K., Jaiswal, A.K., Gonzalez, F.J., Butterworth, B.E., Borghoff, S., Parkinson, H., Everitt, J. and Recio, L., 2003. Genetic susceptibility to benzene-induced toxicity: role of NADPH: quinone oxidoreductase-1. Cancer Res. 63; 929-935.

Baulig, A., Poirault, J.J., Ausset, P., Schins, R., Shi, T., Baralle, D., Dorlhene, P., Meyer, M., Lefevre, R., Baeza-Squiban, A. and Marano, F., 2004. Physicochemical characteristics and biological activities of seasonal atmospheric particulate matter sampling in two locations of Paris. Environ. Sci. Technol. 38, 5985-5992.

Bell, D.A., Taylor, J.A., Paulson, D.F., Robertson, C.N., Mohler, J.L. and Lucier, G.W., 1993. Genetic risk and carcinogen exposure: a common inherited defect of the carcinogen-metabolism gene glutathione S-transferase M1 (GSTM1) that increases susceptibility to bladder cancer. J. Natl. Cancer Inst. 85; 1159-1164.

Brunekreef, B. and Holgate, S., 2002. Air pollution and health. Lancet. 360; 1233-1242.

Buschini, A., Cassoni, F., Anceschi, E., Pasini, L., Poli, P. and Rossi, C., 2001. Urban airborne particulate: genotoxicity evaluation of different size fractions by mutagenesis tests on microorganisms and comet assay. Chemosphere. 44; 1723-1736.

Dagher, Z., Garçon, G., Gosset, P., Ledoux, F., Surpateanu, G., Courcot, D., Aboukais, A., Puskaric, E. and Shirali, P., 2005. Pro-inflammatory effects of Dunkerque city air pollution particulate matter 2.5 in human epithelial lung cells (L132) in culture. J. Appl. Toxicol.. 25; 166-175.

Dahl, A.R. and Lewis, J.L., 1993. Respiratory tract uptake of inhalants and metabolism of xenobiotics. Annu. Rev. Pharmacol. 33; 383-407. 
Dreher, K.L., Jaskot, R.H., Lehmann, J.R., Richards, J.H., McGee, J.K., Ghio, A.J. and Costa, D.L., 1997. Soluble transition metals mediate residual oil fly ash induced acute lung injury. J. Toxicol. Environ. Health. 50; 285-305.

Dubois, M., Pattou, F., Kerr-Conte, J., Gmyr, V., Vandewalle, B., Desreumaux, P., Auwerx, J., Schoonjans, K. and Lefebvre J., 2000. Expression of peroxisome proliferator-activated receptor gamma (PPARgamma) in normal human pancreatic islet cells. Diabetologia., 43, 1165-1169.

Englert, N., 2004. Fine particle and human health - a review of epidemiological studies. Toxicol. Lett. 149; 235-242.

Garçon, G., Zerimech, F., Hannothiaux, M.H., Gosset, P., Martin, A., Marez, T., Shirali, P., 2001. Antioxidant defense disruption by polycyclic aromatic hydrocarbons-coated onto $\mathrm{Fe}_{2} \mathrm{O}_{3}$ particles in human lung cells (A549). Toxicology 166; 129-137.

Garçon, G., Gosset, P., Zerimech, F., Grave-Descampiaux, B. and Shirali P., 2004a. Effect of $\mathrm{Fe}_{2} \mathrm{O}_{3}$ on the capacity of benzo(a)pyrene to induce polycyclic aromatic hydrocarbon-metabolizing enzymes in the respiratory tract of Sprague-Dawley rats. Toxicol. Lett. 150; 179-189.

Garçon, G., Gosset, P., Maunit, B., Zerimech, F., Creusy, C., Müller, J.F., Shirali P., 2004b. Influence of iron $\left({ }^{56} \mathrm{Fe}_{2} \mathrm{O}_{3}\right.$ or $\left.{ }^{54} \mathrm{Fe}_{2} \mathrm{O}_{3}\right)$ in up-regulation of polycyclic aromatic hydrocarbonmetabolizing cytochrome P4501A1 hemoproteins J. Appl. Toxicol. 24; 249-256.

Garçon, G., Dagher, Z., Zerimech, F., Ledoux, F., Courcot, D., Aboukais, A., Puskaric, E., Shirali, P., 2006. Dunkerque city air pollution particulate matter-induced cytotoxicity, oxidative stress and inflammation in human epithelial lung cells (L132) in culture. Toxicol. In Vitro 20; 519-528.

Guengerich, F.P., Johnson, W.W., Ueng, Y.F., Yamazaki, H. and Shimada, T., 1996. Involvement of cytochrome P450, glutathione S-transferase, and epoxide hydrolase in the metabolism of aflatoxin B1 and relevance to risk of human liver cancer. Environ. Health Perspect. 104; 557-562.

Harrison, R.M. and Yin, J., 2000. Particulate matter in the atmosphere: which particle properties are important for its effects on health? Sci. Total. Environ. 248; 85-101.

Hayes, J.D. and Pulford, D.J., 1995a. The glutathione S-transferase supergene family: regulation of GST and the contribution of the isoenzymes to cancer chemoprotection and drug resistance. Crit. Rev. Biochem. Mol. Biol. 30; 445-600.

Hayes, J.D. and Strange, R.C., 1995b. Potential contribution of the glutathione S-transferase supergene family to resistance to oxidative stress. Free Radic. Res. 22; 193-207.

Henderson, R.F., Sabourin, P.J., Bechtold, W.E., Griffith, W.C., Medinsky, M.A., Birnbaum, L.S. and Lucier, G.W., 1989. The effect of dose, dose rate, route of administration, and species on tissue and blood levels of benzene metabolites. Environ. Health Perspect. 82; 9-17.

Hetland, R.B., Cassee, F.R., Refsnes, M., Schwarze, P.E., Lag, M., Boere, A.J.F. and Dybing, E., 2004. Release of inflammatory cytokines, cell toxicity and apoptosis in epithelial lung cells after exposure to ambient air particles of different size fractions. Toxicol. In Vitro $18 ; 203-212$.

Hukkanen, J., Hakkola, J., Anttila, S., Piipari, R., Karjalainen, A., Pelkonen, O. and Raunio, H., 1997. Detection of mRNA encoding xenobiotic-metabolizing cytochrome P450s in human bronchoalveolar macrophages and peripheral blood lymphocytes. Mol Carcinogen. 20; 224-230. 
Hukkanen, J., Lassila, A., Paivarinta, K., Valanne, S., Sarpo, S., Hakkola, J., Pelkonen, O. and Raunio H., 2000. Induction and regulation of xenobiotic-metabolizing cytochrome P450s in the human A549 lung adenocarcinoma cell line. Am. J. Resp. Cell. Mol. 22; 360-366.

Hukkanen, J., Pelkonen, O., Hakkola, J. and Raunio, H., 2002. Expression and regulation of xenobioticmetabolizing cytochrome P450 (CYP) enzymes in human lung. Crit. Rev. Toxicol. 32; 391-411.

Iwanari, M., Nakajima, M., Kizu, R., Hayakawa, K., and Yokoi, T., 2002. Induction of CYP1A1, CYP1A2, and CYP1B1 mRNAs by nitropolycyclic aromatic hydrocarbons in various human tissue-derived cells: chemical-, cytochrome P450 isoform-, and cellspecific differences. Arch. Toxicol. 76; 287-298.

Jaiswal, A.K., 2000. Regulation of genes encoding NAD(P)H:quinone oxidoreductases. Free Radic. Biol. Med. 29; 254-262.

Joseph, P., Jaiswal, A.K., 1994. NAD(P)H:quinone oxidoreductase 1 (DT diaphorase) specifically prevents the formation of benzo-(a)pyrene quinone-DNA adducts generated by cytochrome P4501A1 and P450 reductase. Proc. Natl. Acad. Sci. USA 91; 8413-8417.

Koop, D.R., Laethem, C.L. and Schnier, G.G., 1989. Identification of ethanol-inducible P450 isozyme 3a (P450IIE1) as a benzene and phenol hydroxylase. Toxicol. Appl. Pharmacol. 98; 278-288.

Levy, J.I., Hammit, J.K. and Spengler, J.D., 2000. Estimating the mortality impacts of particulate matter: what can be learned from between-study variability? Environ. Health Perspect. 108; 109-117.

Liden, J., Ek, A., Palmberg, L., Okret, S. and Larsson, K., 2003. Organic dust activates NF$\kappa \mathrm{B}$ in lung epithelial cells. Respir. Med. 97; 882-892.

Macé, K., Bowman, E.D., Vautravers, P., Shields, P.G., Harris, C.C. and Pfeifer, A.M.A., 1998. Characterisation of Xenobiotic-metabolising Enzyme Expression in Human Bronchial Mucosa and Peripheral Lung Tissues. Eur. J. Cancer. 34; 914-920.

Monn, C. and Becker, S., 1999. Cytotoxicity and induction of proinflammatory cytokines from human monocytes exposed to fine (PM2.5) and coarse particles (PM10-2.5) in outdoor and indoor air. Toxicol. Appl. Pharmacol. 155; 245-252.

Nel, A.E., Diaz-Sanchez, D. and Li, N., 2001. The role of particulate pollutants in pulmonary inflammation and asthma: evidence for the involvement of organic chemicals and oxidative stress. Curr. Opin. Pulm. Med. 7; 20-26.

Nichols, W.K., Mehta, R., Skordos, K., Macé, K., Pfeifer, A.M.A., Carr, B.A., Minko, T., Burchiel, S.W. and Yost, G.S., 2003. 3-Methylindole-Induced Toxicity to Human Bronchial Epithelial Cell Lines. Toxicol. Sci.,71, 229-236.

Osornio-Vargas, A.R., Bonner, J.C., Alfaro-Moreno, E., Martinez, L., Garcia-Cuellar, C., Ponce-de-Leon Rosales, S., Miranda, J. and Rosas, I., 2003. Proinflammatory and cytotoxic effects of Mexico city air pollution particulate matter in vitro are dependent on particle size and composition. Environ. Health Perspect. 111; 1289-1293.

Piipari, R., Nurmimen, T., Savela, K., Hirvonen, A., Mäntylä, T., Antilla, S., 2003. Glutathione S-Transferases and aromatic DNA adducts in smokers' bronchoalveolar macrophages. Lung Cancer. 39; 265-272.

Powley, M.W. and Carlson, G.P., 1999. Species comparison of hepatic and pulmonary metabolism of benzene. Toxicology 139; 207-217. 
Rossi, A.M., Guarnieri, C., Rovesti, S., Gobba, F., Ghittori, S., Vivoli, G. and Barale, R., 1999. Genetic polymorphisms influence variability in benzene metabolism in humans. Pharmacogenetics. 9; 445-451.

Runge, D.M., Stock, T.W., Lehmann, T., Taege, C., Bernauer, U., Stolz, D.B., Hofmann, S. and Foth H., 2001. Expression of cytochrome P450 2E1 in normal human bronchial epithelial cells and activation by ethanol in culture. Arch. Toxicol. 75; 335-345.

Schlesinger, R.B., Kunzli, N., Hidy, G.M., Gotschi, T. and Jerrett, M., 2006. The health relevance of ambient particulate matter characteristics: coherence of toxicological and epidemiological inferences. Inhal Toxicol. 18; 95-125.

Sheets, P.L., Yost, G.S. and Carlson, G.P., 2004. Benzene metabolism in human lung cell lines BEAS2B and A549 and cells overexpressing CYP2F1. J. Biochem. Mol. Toxic 18; 92-99.

Shirali, P., Gosset, P., Marez, T., Hachimi, A., Muller, J.F. and Haguenoer, J.M., 1995. Cytotoxicity evaluation of hematite $\left(\mathrm{Fe}_{2} \mathrm{O}_{3}\right)$, benzo(a)pyrene and pyrene and analysis of particles by Laser Microprobe Mass Analyser (in-vitro). Cell Biol. Toxicol. 11; 215.

Soukup, J.M. and Becker, S., 2001. Human alveolar macrophage responses to air pollution particulates are associated with insoluble components of coarse material, including particulate endotoxin. Toxicol. Appl. Pharmacol. 171; 20-26.

Spivack, S.D., Hurteau, G.J., Fasco, M.J. and Kaminsky, L.S., 2003. Phase I and II Carcinogen Metabolism Gene Expression in Human Lung Tissue and Tumors. Clin. Cancer Res. 9; 60026011.

Thier, R., Bruning, T., Roos, P.H., Rihs, H.P., Golka, K., Ko, Y. and Bolt, H.M., 2003. Markers of genetic susceptibility in human environmental hygiene and toxicology: the role of selected CYP, NAT and GST genes. Int. J. Hyg. Environ. Health. 206; 149-171.

Vakharia, D.D., Liu, N., Pause, R., Fasco, M., Bessette, E., Zhang, Q.Y. and Kaminsky, L.S., 2001a.. Effect of metals on polycyclic aromatic hydrocarbon induction of CYP1A1 and CYP1A2 in human hepatocyte cultures. Toxicol Appl Pharm. 170; 93-103.

Vakharia, D.D., Liu, N., Pause, R., Fasco, M., Bessette, E., Zhang, Q.Y. and Kaminsky, L.S., 2001b. Polycyclic aromatic hydrocarbon/metal mixtures: effect on PAH induction of CYP1A1 in human HEPG2 cells. Drug Metab Dispos. 29; 999-1006.

Warren, J., 2002. Health Effects Institute - Particulate Measurements Necessary for Health Research San Diego, CA, USA Coordinating Research Council October 21.

Wiemels J., Wiencke J.K., Varykoni A., Smith M.T. 1999. Modulation of the toxicity and macromolecular binding of benzene metabolites by $\mathrm{NAD}(\mathrm{P}) \mathrm{H}$ :Quinone oxidoreductase in transfected HL-60 cells. Chem. Res. Toxicol. 12; 467-75.

Willey, J.C, Coy, E., Brolly, C., Utell, M.J., Frampton, M.W., Hammersley, J., Thilly, W.G., Olson, D. and Cairns, K., 1996. Xenobiotic metabolism enzyme gene expression in human bronchial epithelial and alveolar macrophage cells. Am. J. Resp. Cell. Mol. 14; 262-271. 


\section{FigURES}

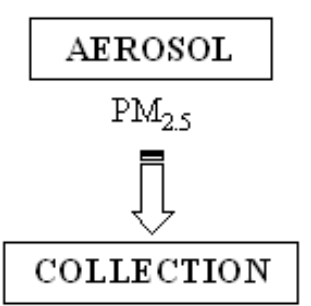

High volume cascade impactor

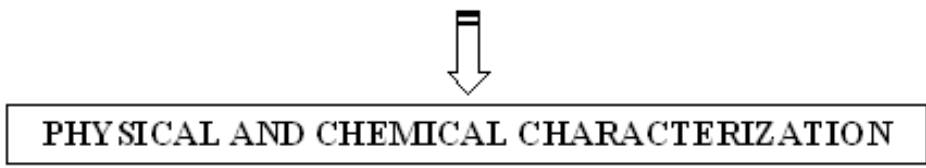

- Size distribution (SEM-EDX)

- Specific surface area (BET method)

- Inorganic elements (ICP-AES)

- Ions (IC and spectrophotometry)

- Organic chemicals (GC/MS)

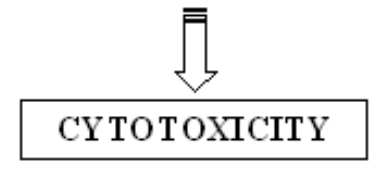

Lung target: A549 cell line

Incubation time: 24,48 or $72 \mathrm{~h}$; or 9 days

PM concentrations: 18.84 to $150.72 \mu \mathrm{g} / \mathrm{mL}\left(4.61\right.$ to $\left.91.35 \mu \mathrm{g} / \mathrm{cm}^{2}\right)$

- BrdU incorporation to DNA

- MDH activity in cells

- LDH activity in cell-free culture supernatants

- Colony forming method

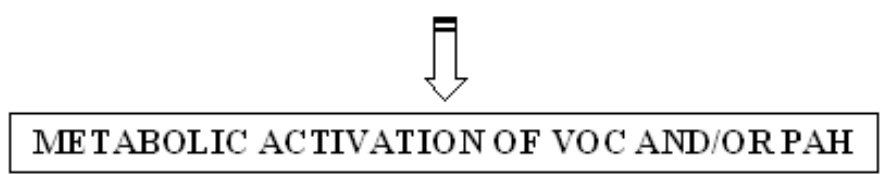

Lung target: A549 cell line Incubation time: 24,48 or $72 \mathrm{~h}$

PM concentrations: $\mathrm{LC} 10=23.72 \mu \mathrm{g} / \mathrm{mL}\left(6.33 \mu \mathrm{g} / \mathrm{cm}^{2}\right)$, and LC50 $=118.60 \mu \mathrm{g} / \mathrm{mL}\left(31.63 \mu \mathrm{g} / \mathrm{cm}^{2}\right)$

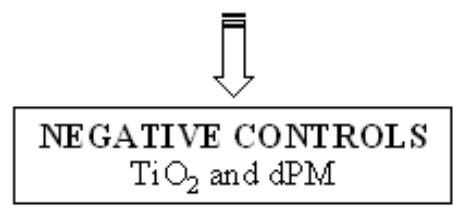

I
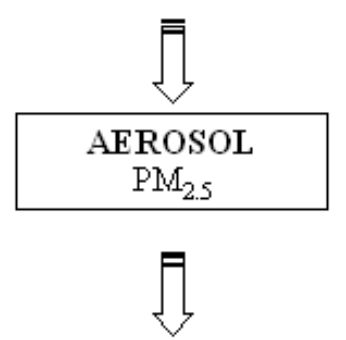
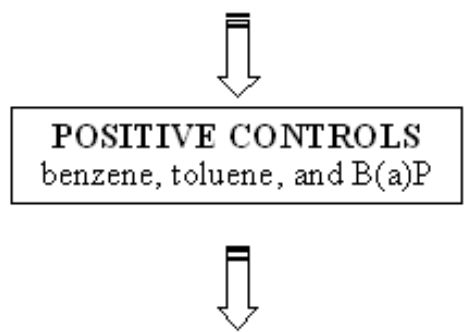

mRNA expression of VOC and/or PAH-metabolizing enzym es (RT-PCR)

- $\varphi$ 1: cyp 1a 1, cyp2e1, cyp2f1, meh, nqo

- $\varphi 2$ : gst- $\mu 1$, gst- $\mu 3$, and gst- $\pi 1$ 
Figure 1: This work consisted in a multi-step approach including the collection of particle matter (PM), the determination of its physical and chemical characteristics, the evaluation of its cytotoxicity in A549 cells, and the study of the metabolic activation of volatile organic compound (VOC) and/or polycyclic aromatic hydrocarbon (PAH)-coated onto collected PM by A549 cells. (Scanning electron microscopy coupled with energy dispersive X-ray, SEMEDX; Brunauer, Emmett, and Teller, BET; inductively coupled plasma-atomic emission spectrometry, ICP-AES; ionic chromatography, IC; gas chromatography-mass spectrometry, GC/MS; 5-bromo-2-deoxyuridine, BrdU; mitochondrial dehydrogenase, MDH; lactate dehydrogenase, LDH; desorbed particulate matter, dPM; benzo(a)pyrene, B(a)P).

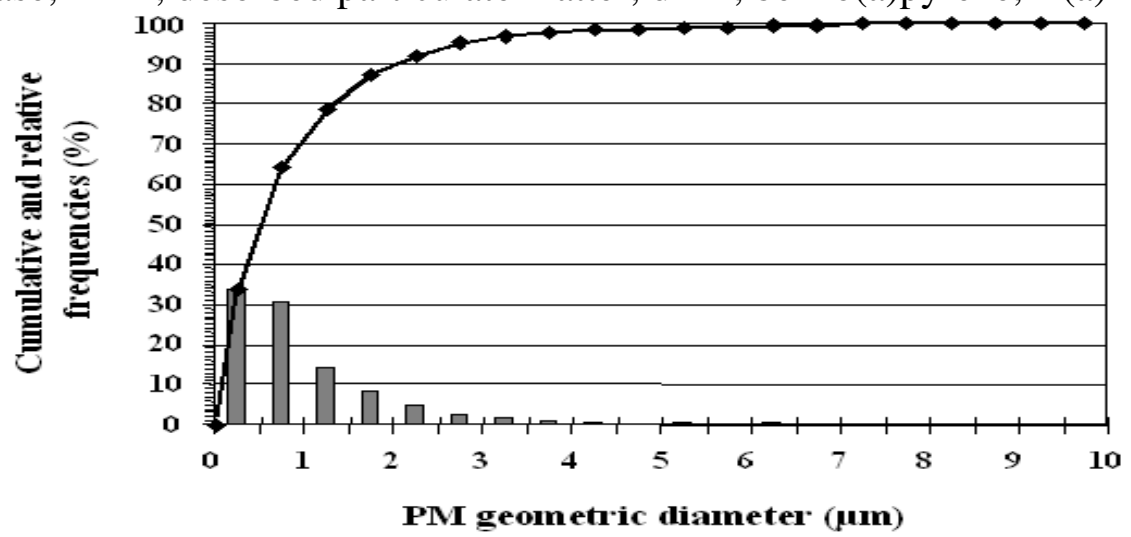

Figure 2: Size distribution of the particle matter (PM) collected in Dunkerque, a French seaside city located on the southern coast of the North-Sea, using high volume cascade impactor, is depicted as cumulative frequency (\%; curve) and relative frequency (\%; histogram). PM size distribution has been determined using scanning electron microscopy.

(a)

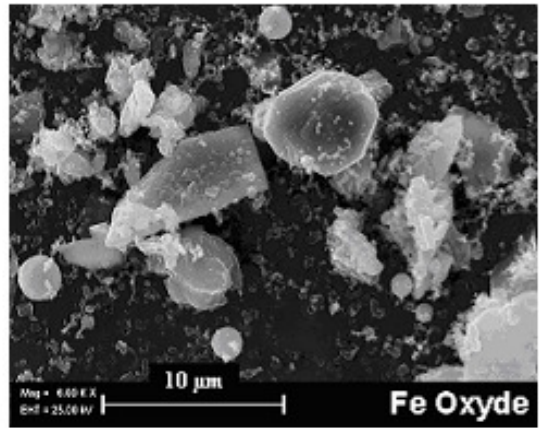

(b)

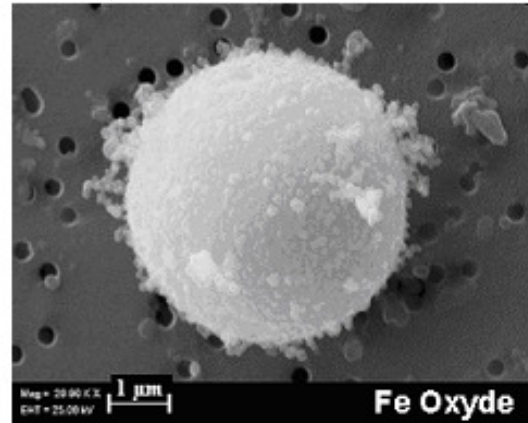

Figure 3: Scanning electron microscopy coupled with energy dispersive $X$-ray analysis of $\mathrm{Fe}$ oxides in collected particle matter: (a) natural origin; (b) anthropogenic origin.

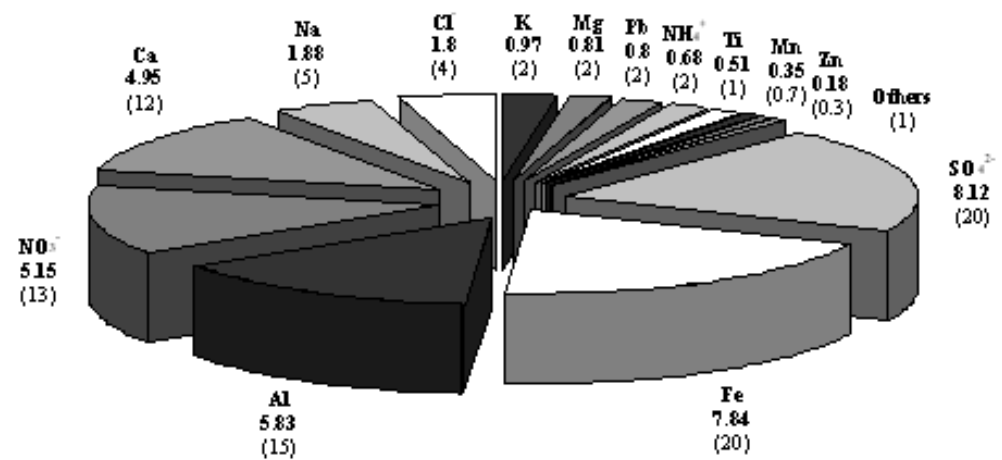

Figure 4: Inorganic compounds detected in collected particle matter (PM) by inductively coupled plasma-atomic emission spectrometry (ICP-AES), ionic chromatography $\left(\mathrm{Cl}^{-}, \mathrm{NO}_{3}{ }^{-}\right.$ and $\mathrm{SO}_{4}{ }^{2-}$ ), or visible spectrophotometry $\left(\mathrm{NH}_{4}{ }^{+}\right.$) (percentage $\mathrm{m} / \mathrm{m}$ of total $\mathrm{PM}$ in bold, and of the inorganic fraction in brackets). 


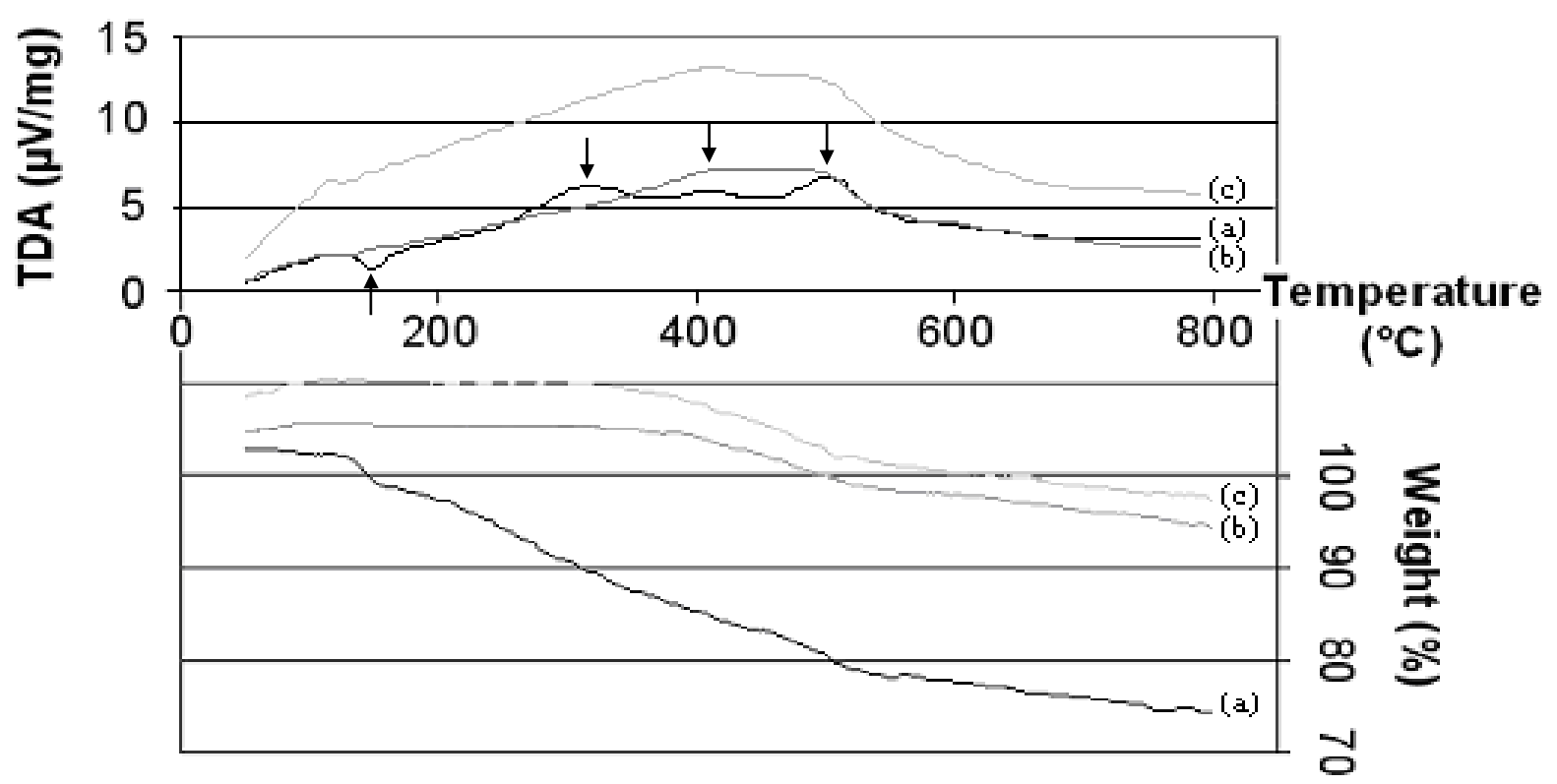

Figure 5: Thermogravimetric and differential thermal analysis (TG-DTA) of the particle matter (PM): (a) native collected PM, (b) $500^{\circ} \mathrm{C}-\mathrm{GC} / \mathrm{MS}$-analyzed $\mathrm{PM}$, and (c) $400^{\circ} \mathrm{C}$ outgassed under secondary vacuum-PM (desorbed PM; dPM). ( $\uparrow$ : endothermic peak; $\downarrow$ : exothermic peak).

(a)

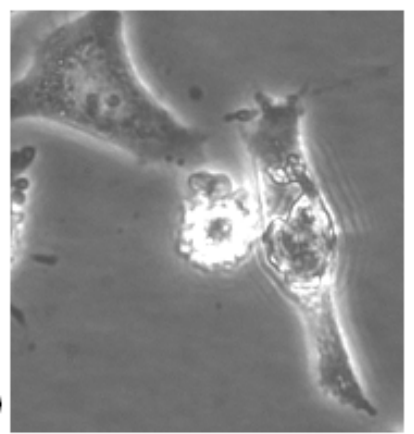

(b)

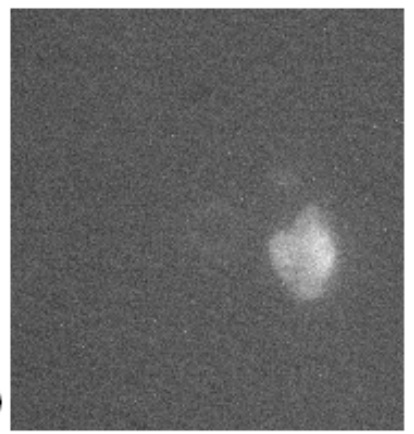

Figure 6: Contrast phase microscopy observations of particle matter-exposed A549 cells (Magnification: $400 \mathrm{x}$ ): (a) White light (b) Rhodamin (excitation: $570 \mathrm{~nm}$; emission $590 \mathrm{~nm}$ ).

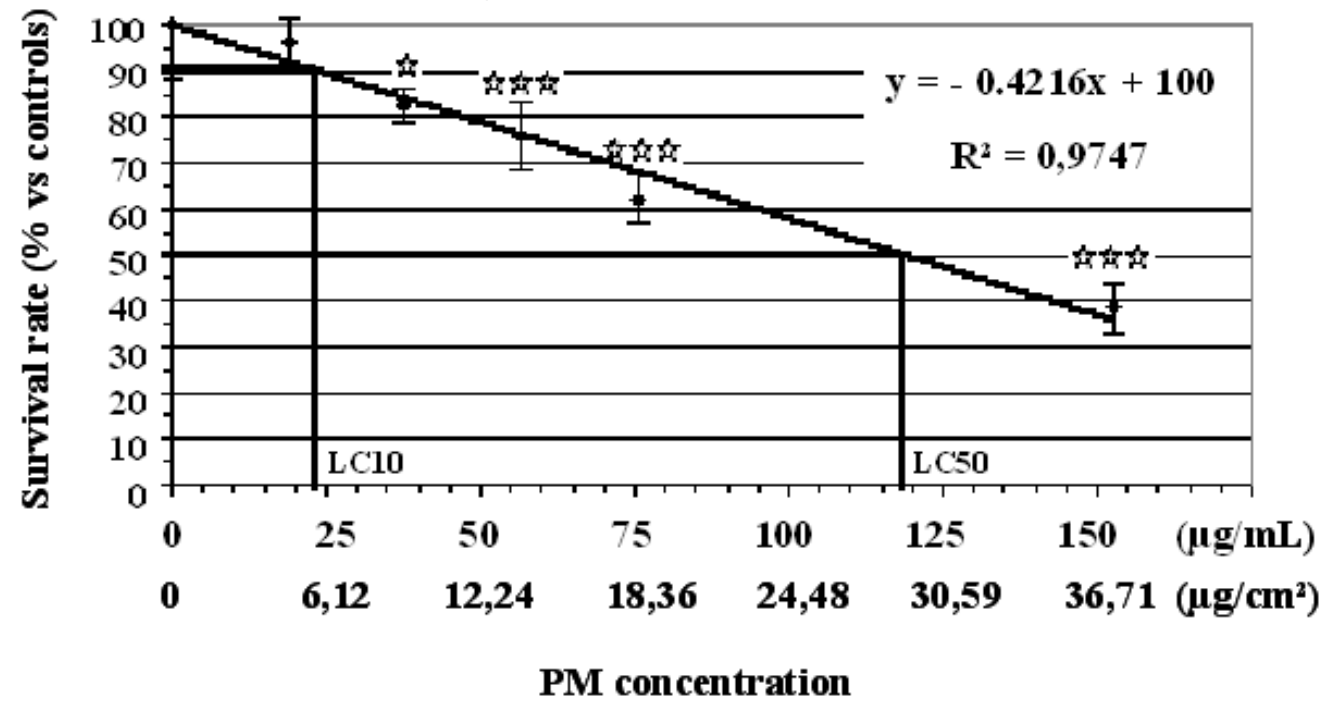


Figure 7: Survival rates (\%) of A549 cells 9 days after their incubation in the continuous presence of increasing concentrations of collected particle matter (PM; 18.84, 37.68, 56.52, 75.36 or $150.72 \mu \mathrm{g} \mathrm{PM} / \mathrm{ml}$; or $4.61,9.22,13.83,18.45$ or $36.89 \mu \mathrm{g} \mathrm{PM} / \mathrm{cm}^{2}$ ) without renewing the culture media. Non-exposed cells were used as negative controls. These values are depicted as mean values and standard deviation of 10 cell cultures for negative controls and 5 cell cultures for every PM concentrations. Lethal concentrations at $10 \%$ and $50 \%\left(\mathrm{LC}_{10}\right.$ and $\mathrm{LC}_{50}$, respectively) were calculated comparing the number of crystal violet-stained cell colonies in exposed culture dishes with the number in non exposed culture dishes: $\mathrm{LC}_{10}=$ $23.72 \mu \mathrm{g} \mathrm{PM} / \mathrm{ml}$ (or $5.81 \mu \mathrm{g} \mathrm{PM} / \mathrm{cm}^{2}$ ) and $\mathrm{LC}_{50}=118.60 \mu \mathrm{g} \mathrm{PM} / \mathrm{ml}\left(\right.$ or $29.03 \mu \mathrm{g} \mathrm{PM} / \mathrm{cm}^{2}$ ). (Mann-Whitney U test; vs controls; *: p<0.05; ***: p<0.001).

Table 1: Sequence of the Primers for the Study of the mRNA Expression of VOC and/or PAH-Metabolizing Enzymes

\begin{tabular}{|c|c|c|c|}
\hline Gene & Primers sequences & $\begin{array}{l}\text { Size } \\
(\mathrm{bp})\end{array}$ & Reference \\
\hline cyp lal & $\begin{array}{l}\text { S 5'-TCT TTC TCT TCC TGG CTA TC-3' } \\
\text { AS 5'-CTG TCT CTT CCC TTC ACT CT-3' }\end{array}$ & 596 & Iwanari et al., 2002 \\
\hline cyp $2 e 1$ & $\begin{array}{l}\text { S 5'-TGC CAT CAA GGA TAG GCA AG-3' } \\
\text { AS 5'-AAT GCT GCA AAT GGC ACA C-3' }\end{array}$ & 356 & Macé et al., 1998 \\
\hline cyp $2 f 1$ & $\begin{array}{c}\text { S 5'-GCT GCG GAA AAC TGA AGG-3' } \\
\text { AS 5'-GCC AAA GAG CAG GTT ATG TGT-3' }\end{array}$ & 427 & Nichols et al., 2003 \\
\hline meh & $\begin{array}{l}\text { S 5'-TGA GCG GAT GAA GGT CTA TG-3' } \\
\text { AS 5'-TCA AAG CCA TGT TGC TTA CC-3', }\end{array}$ & 401 & NCBI GenBank \\
\hline nqol & $\begin{array}{l}\text { S 5'-TGA AGA AGA AAG GAT GGG AGG-3' } \\
\text { AS 5'-AGG GGG AAC TGG AAT ATC AC-3' }\end{array}$ & 223 & Spivack et al., 2003 \\
\hline$g s t-\mu 1$ & $\begin{array}{l}\text { S 5'-ACT TTC CCA ATC TGC CCT AC-3' } \\
\text { AS 5'- TTC TGG ATT GTA GCA GAT CA-3' }\end{array}$ & 191 & Spivack et al., 2003 \\
\hline gst- $\mu 3$ & $\begin{array}{l}\text { S 5'-ACT TTC CTA ATC TGC CCT ACC -3' } \\
\text { AS 5'-TAA CAC ACC TGC TCT CTC C-3' }\end{array}$ & 805 & Spivack et al., 2003 \\
\hline$g s t-\pi 1$ & $\begin{array}{l}\text { S 5'-CAC CAA CTA TGA GGC GGG CAA-3' } \\
\text { AS 5'- ATC AGC AGC AAG TCC AGC A-3' }\end{array}$ & 159 & Spivack et al., 2003 \\
\hline$\beta$-actin & $\begin{array}{l}\text { S 5'-ATC ATG TTT GAG ACC TTC AA-3' } \\
\text { AS 5'-CAT CTC TTG CTC GAA GTC CA-3' }\end{array}$ & 314 & Dubois et al., 2000 \\
\hline
\end{tabular}

Table 1 presents the sequences of the Sense (S) and Antisense (AS) primers for the study of the mRNA expression of volatile organic compounds (VOC) and/or polycyclic aromatic hydrocarbons (PAH)metabolizing enzymes: cytochrome P450 (cyp) 1a1, cyp 2e1, cyp 2f1, microsomal epoxyde hydrolase (meh),

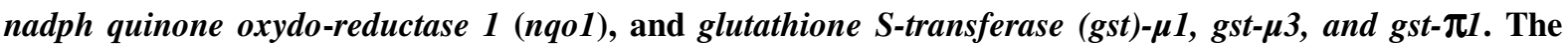
primers for meh (Accession no. NM_000120) were designed by sequence information of the National Center for Biotechnology Information (NCBI) Genbank (Accession n ${ }^{\circ}$ M_000120) and Primer 3 Input v02 software (bp = base pairs). 
Table 2: Organic Compounds Detected in the Collected PM after Thermal Desorption and Gas Chromatography-Mass Spectrometry Analyses

\begin{tabular}{|c|c|}
\hline Compound & $\mathrm{C}(\mathrm{ppm})$ \\
\hline Benzene & 106.5 \\
Toluene & 42.2 \\
Nonene & 9.3 \\
Xylene & 65.4 \\
Styrene & 13.5 \\
1-Ethenyltrimethylbenzene & 15.4 \\
Decane & 64.9 \\
Diethylbenzene & 170.3 \\
Limonene epoxyde & 20.5 \\
Tetramethylbenzene & $\mathbf{8 9 . 5}$ \\
Naphtalene & 38.1 \\
Methylnaphtalene & 141.9 \\
Dimethylnaphtalene & 90.2 \\
Heptadecane & 15.1 \\
Anthracene & 47.1 \\
\hline
\end{tabular}

\begin{tabular}{|c|c|}
\hline Compound & C $(\mathrm{ppm})$ \\
\hline Phenanthrene & 28.3 \\
Dibutylphtalate & 110.1 \\
Eicosane & 1.4 \\
Fluoranthene & 4.7 \\
Henicosane & 5.2 \\
Docosane & 17.4 \\
Tricosane & 8.7 \\
Tetracosane & 39.7 \\
Pentacosane & 12.2 \\
Bis(Ethyl.Hexyl)phtalate & 41.4 \\
Acenaphtene & 11.1 \\
Fluorene & 6.3 \\
Pyrene & 4.7 \\
Benzo(a)anthracene & 4.9 \\
or Chrysene & \\
\hline
\end{tabular}

Table 2 shows the list of the organic compounds detected in the collected particulate matter (PM). The concentrations are expressed in $\mathrm{ppm}(\mu \mathrm{g} / \mathrm{g})$. 
Table 3: PM Cytotoxicity in A549 cells

\begin{tabular}{|c|c|c|c|c|c|c|c|}
\hline & \multirow[b]{2}{*}{$(\mu \mathrm{g} / \mathrm{mL})$} & \multicolumn{6}{|c|}{ PM EXPOSURE } \\
\hline & & 0 & 18.84 & 37.68 & 56.52 & 76.36 & 150.72 \\
\hline & $\left(\mu \mathrm{g} / \mathrm{cm}^{2}\right)$ & 0 & 11.42 & 22.84 & 34.25 & 45.67 & 91.35 \\
\hline \multirow{6}{*}{$\underset{D}{\rightleftharpoons}$} & \multirow{2}{*}{$24 \mathrm{~h}$} & 100.0 & 98.8 & $92.6 *$ & $75.3 * * *$ & $69.8 * * *$ & $76.3 * * *$ \\
\hline & & \pm 6.5 & \pm 5.3 & \pm 6.2 & \pm 4.3 & \pm 4.3 & \pm 2.1 \\
\hline & \multirow{2}{*}{$48 \mathrm{~h}$} & 100.0 & 94.9 & 88.6* & $88 *$ & $85.7 *$ & $86.9 *$ \\
\hline & & \pm 11.3 & \pm 7.9 & \pm 4.5 & \pm 4.6 & \pm 9.1 & \pm 5.0 \\
\hline & \multirow{2}{*}{$72 \mathrm{~h}$} & 100.0 & 85.4 & $83.6^{*}$ & $73.4 * * *$ & $69.1 * * *$ & $76.5 * * *$ \\
\hline & & \pm 12.6 & \pm 16.7 & \pm 12.8 & \pm 7.9 & \pm 12.4 & \pm 5.3 \\
\hline \multirow{6}{*}{$\stackrel{\mathrm{I}}{\mathrm{I}}$} & \multirow{2}{*}{$24 \mathrm{~h}$} & 100.0 & 90.7 & $75.8 * * *$ & $72.1 * * *$ & $64.1 * * *$ & $58 * * *$ \\
\hline & & \pm 8.8 & \pm 3.9 & \pm 5.7 & \pm 2.9 & \pm 3.4 & \pm 2.2 \\
\hline & \multirow{2}{*}{$48 \mathrm{~h}$} & 100.0 & 96.1 & $88.2 *$ & 88.1* & $84.1 * * *$ & $73.4 * * *$ \\
\hline & & \pm 8.4 & \pm 5.7 & \pm 9.5 & \pm 8.7 & \pm 2.5 & \pm 10.4 \\
\hline & \multirow{2}{*}{$72 \mathrm{~h}$} & 100.0 & 102.6 & 102.3 & 99.2 & $91.1 * * *$ & $78.5 * * *$ \\
\hline & & \pm 5.4 & \pm 6.1 & \pm 6.8 & \pm 6.1 & \pm 6.0 & \pm 2.3 \\
\hline \multirow{6}{*}{$\stackrel{\sqrt{3}}{\Omega}$} & \multirow{2}{*}{$24 \mathrm{~h}$} & 100.0 & 90.1 & 104.6 & 85.9 & 95.2 & 82.0 \\
\hline & & \pm 10.4 & \pm 12.5 & \pm 15.8 & \pm 7.7 & \pm 8.5 & \pm 18.1 \\
\hline & \multirow{2}{*}{$48 \mathrm{~h}$} & 100.0 & 112.4 & 96.1 & 89.8 & 100.3 & 83.9 \\
\hline & & \pm 12.0 & \pm 12.7 & \pm 10.0 & \pm 8.5 & \pm 7.1 & $\pm \mathbf{3 . 0}$ \\
\hline & \multirow{2}{*}{$72 \mathrm{~h}$} & 100.0 & 99.4 & 98.6 & 99.3 & 107.1 & $115.1 * * *$ \\
\hline & & \pm 5.8 & \pm 4.6 & \pm 4.2 & \pm 4.7 & \pm 9.6 & \pm 5.6 \\
\hline
\end{tabular}

Incorporation of 5-bromo-2-deoxyuridine (BrdU) and mitochondrial dehydrogenase (MDH) activity (\% vs controls) in A549 cells, and released lactate dehydrogenase (LDH) activity (\% vs controls) in cell-free culture supernatants of A549 cells 24, 48 or 72h after their incubation in the continuous presence of increasing concentrations of particle matter $(\mathrm{PM} ; 18.84,37.68,56.52$ or $75.36 \mu \mathrm{g} \mathrm{PM} / \mathrm{mL}$; or 11.42 , 22.64, 34.25, 45.67 or $91.35 \mu \mathrm{g} \mathrm{PM} / \mathrm{cm}^{2}$ ) without renewing the culture media. Non-exposed cells were used as negative controls. These values are depicted as mean values and standard deviations of 16 replicates for negative controls and 8 replicates for every PM concentrations (Mann-Whitney $U$ test; vs controls; *: $\mathbf{p}<0.05 ; * * *: \mathbf{p}<0.001)$. 
Table 4: Metabolic Activation of the VOC and/or PAH-Coated onto PM: Cytochromes P-450

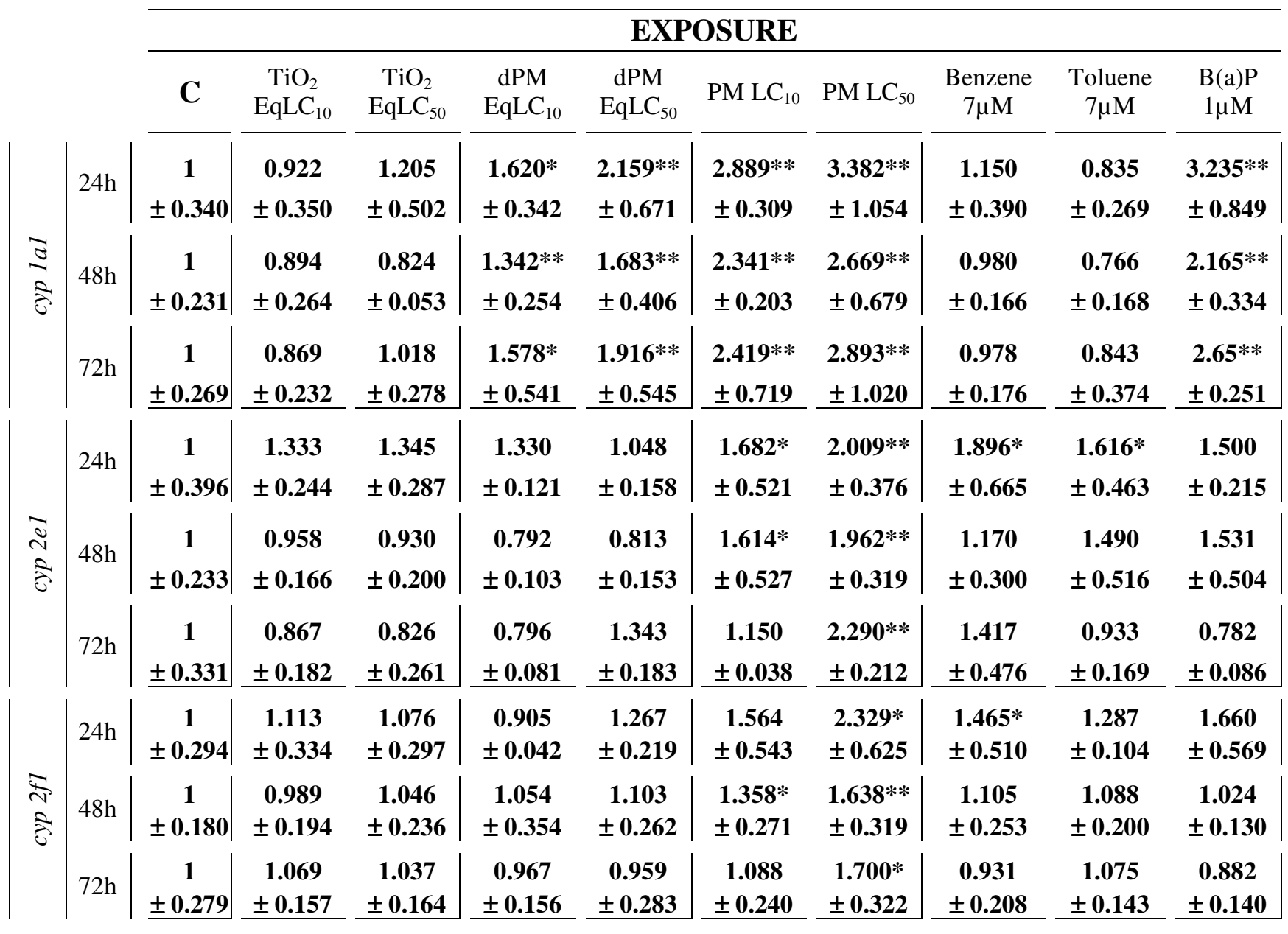

Gene expressions of cytochrome P450 (cyp) 1a1, cyp2e1, and cyp2f1 (fold-induction vs controls) in $\mathrm{A549}$ cells 24, 48 or $72 \mathrm{~h}$ after their exposure. Cells exposed to $\mathrm{TiO}_{2}(<0.2 \mu \mathrm{m})$ or to desorbed particulate matter (dPM) at equivalent concentrations to inorganic $L C_{10}\left(E q C_{10}=19.42 \mu \mathrm{g}\right.$ $\mathrm{PM} / \mathrm{mL}$ or $\left.5.18 \mu \mathrm{g} \mathrm{PM} / \mathrm{cm}^{2}\right)$ or $\mathrm{LC}_{50}\left(\mathrm{Eq} \mathrm{LC}_{50}=97.13 \mu \mathrm{g} \mathrm{PM} / \mathrm{mL}\right.$ or $\left.25.90 \mu \mathrm{g} \mathrm{PM} / \mathrm{cm}^{2}\right)$ ), integrating weight losses due to the organic desorption, were used as negative controls. Other cells were exposed to particulate matter $(\mathrm{PM})$ at their $\mathrm{LC}_{10}$ (i.e. $23.72 \mu \mathrm{g} \mathrm{PM} / \mathrm{mL}$ or $6.33 \mu \mathrm{g}$ $\mathrm{PM} / \mathrm{cm}^{2}$ ) or $\mathrm{LC}_{50}$ (i.e. 118.60 $\mu \mathrm{g} \mathrm{PM} / \mathrm{ml}$ or $31.63 \mu \mathrm{g} \mathrm{PM} / \mathrm{cm}^{2}$ ). Moreover, cells exposed to benzene, toluene and benzo(a)pyrene $(B(a) P)$ served as positive controls for the induction of the mRNA expression of volatile organic compounds (VOC) and/or polycyclic aromatic hydrocarbons (PAH)-metabolizing enzymes. These values are depicted as mean values and standard deviation of 8 replicates for controls (C), and 4 replicates for negative controls, every PM concentrations, and positive controls (Mann-Whitney U-test; vs controls; *: p<0.05; **: $\mathbf{p}<\mathbf{0 . 0 1 )}$. 
Table 5: Metabolic Activation of the VOC and/or PAH-Coated onto PM: Other Enzymes

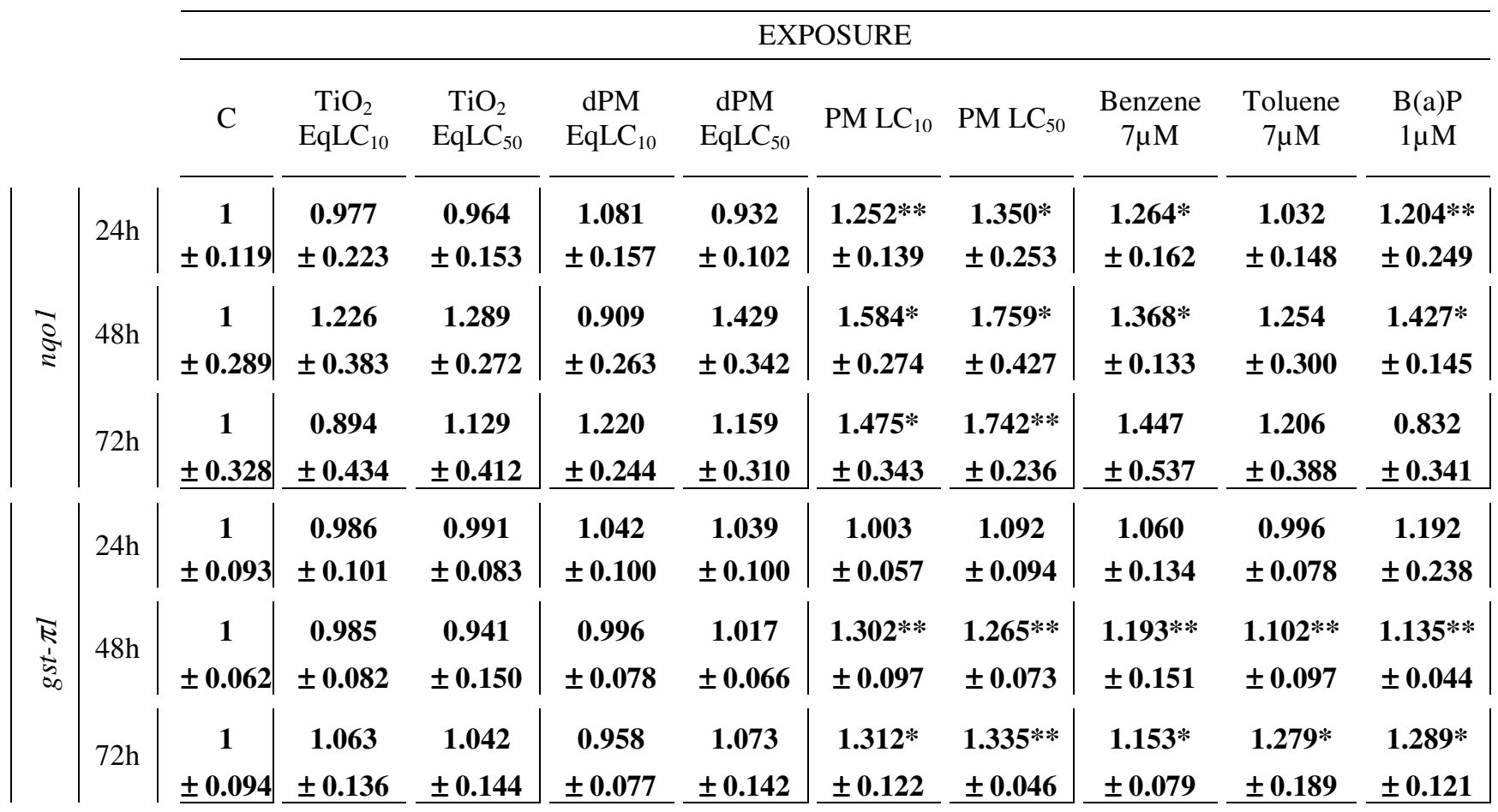

Gene expressions of the NADPH quinone oxydo-reductase-1 (nqo1) and glutathione S-transferase-pi 1 (gst$\pi \mathrm{l}$ ) (fold-induction vs controls) in $\mathrm{A549}$ cells 24, 48 or $72 \mathrm{~h}$ after their exposure. Cells exposed to $\mathrm{TiO}_{2}$ $(<0.2 \mu \mathrm{m})$ or to desorbed particulate matter $(\mathrm{dPM})$ at equivalent concentrations to inorganic $\mathrm{LC}_{10}\left(\mathrm{Eq}_{\mathbf{q}}\right.$ $\mathrm{LC}_{10}=19.42 \mu \mathrm{g} \mathrm{PM} / \mathrm{mL}$ or $\left.5.18 \mu \mathrm{g} \mathrm{PM} / \mathrm{cm}^{2}\right)$ or $\mathrm{LC}_{50}\left(\mathrm{Eq} \mathrm{LC}_{50}=97.13 \mu \mathrm{g} \mathrm{PM} / \mathrm{mL}\right.$ or $\left.\left.25.90 \mu \mathrm{gM} / \mathrm{cm}^{2}\right)\right)$, integrating weight losses due to the organic desorption, were used as negative controls. Other cells were exposed to particulate matter $(P M)$ at their $L_{10}$ (i.e. $23.72 \mu \mathrm{g} P \mathrm{PML} / \mathrm{mL}$ or $6.33 \mu \mathrm{g} \mathrm{PM} / \mathrm{cm}^{2}$ ) or $\mathrm{LC}_{50}$ (i.e. 118.60 $\left.\mu \mathrm{g} \mathrm{PM/ml} \mathrm{or} 31.63 \mu \mathrm{g} P M / \mathrm{cm}^{2}\right)$. Moreover, cells exposed to benzene, toluene and benzo(a)pyrene (B(a)P) served as positive controls for the induction of the mRNA expression of volatile organic compounds (VOC) and/or polycyclic aromatic hydrocarbons (PAH)-metabolizing enzymes. These values are depicted as mean values and standard deviation of 8 replicates for controls (C), and 4 replicates for negative controls, every PM concentrations, and positive controls (Mann-Whitney U-test; vs controls; *: $\mathbf{p}<0.05 ; * *$ : $\mathbf{p}<0.01)$. 